\title{
Perkembangan Spodoptera frugiperda J.E Smith Pada Tanaman Jagung Manis (Zea mays L. Saccharata)
}

\author{
${ }^{* 1}$ Wilyus, ${ }^{1}$ Hamdan Maruli Siregar dan ${ }^{2}$ Rizki Aulia \\ ${ }^{1}$ Fakultas Pertaian Universitas Jambi \\ ${ }^{2}$ Alumni Fakultas Pertanian Universitas Jambi \\ Jl. Raya Jambi Muara Bulian Km 15 Desa Mendalo Indah 36361 \\ ${ }^{* 1}$ e-mail korespondensi : wilyus@unja.ac.id
}

\begin{abstract}
This study was conducted to determine the relationship between sweet corn plant phenology and population development and the attack of Spodoptera frugiperda. The research was carried out at the Research Farm and at the Laboratory of Plant Pests, Faculty of Agriculture, Jambi University. The study was conducted on an area of $500 \mathrm{~m}^{2}$ containing 28 plant plots. The sample plants consisted of 4 plots determined systematically. In each sample plot, all plants were used as sample. plants to calculate the percentage of attacked plants, and the percentage of attacked cobs. S. frugiperda population observations were carried out directly on leaves, stems, flowers and cobs. If there were S. frugiperda faeces on the shoots, stems, and cobs, destructive observations were made where the plant parts were opened, to determine the presence of $S$. frugiperda in them. The data obtained were tabulated and arranged in the form of tables and figures, then explained descriptively. The results showed that:the population of $S$. frugiperda in each growth phase continued to increase, the highest population of S. frugiperda was found in the R6 phase or in the physiological ripening phase, which was as many as 21 heads per 12 corn plants; the percentage of attacks of $S$. frugiperda in each phase continues to increase, the highest percentage of attacks is in phase R6, which is 78.72\%; the attack of S. frugiperda on cobs began to be seen in the R2-R5 phase and was highest in the R6 phase, which was 68.57\%. It is necessary to find the right way to control S. frugiferda.
\end{abstract}

Keywords: S. frugiperda, phenology, sweet corn

\begin{abstract}
Abstrak. Penelitian ini dilakukan untuk mengetahui hubungan antara fenologi tanaman jagung manis dengan perkembangan populasi dan serangan Spodoptera frugiperda. Penelitian dilaksanakan di research farm dan di laboratorium Hama Tanaman Fakultas Pertanian Universitas Jambi. Penelitian dilakukan pada lahan seluas $500 \mathrm{~m}^{2}$ yang terdiri dari 28 plot tanaman. Tanaman contoh terdiri dari 4 petak yang ditentukan secara sistematis. Pada setiap petak sampel, semua tanaman digunakan sebagai sampel. tanaman untuk menghitung persentase tanaman yang terserang, dan persentase tongkol yang terserang. Pengamatan populasi $S$. frugiperda dilakukan secara langsung pada daun, batang, bunga dan tongkol. Jika terdapat feses $S$. frugiperda pada pucuk, batang, dan tongkol, dilakukan pengamatan destruktif pada bagian tanaman yang tersebut untuk mengetahui keberadaan S. frugiperda di dalamnya. Data yang diperoleh ditabulasi dan disusun dalam bentuk tabel dan gambar, kemudian dijelaskan secara deskriptif. Hasil penelitian menunjukkan bahwa: populasi S. frugiperda pada setiap fase pertumbuhan terus meningkat, populasi $S$. frugiperda tertinggi terdapat pada fase R6 atau fase pematangan fisiologis yaitu sebanyak 21 ekor per 12 tanaman jagung. ; persentase serangan $S$. frugiperda pada setiap fase terus meningkat, persentase serangan tertinggi berada pada fase R6 yaitu 78,72\%; serangan $S$. frugiperda pada tongkol mulai terlihat pada fase R2-R5 dan tertinggi pada fase R6 yaitu sebesar $68,57 \%$. Untuk itu perlu dicari cara yang tepat untuk mengendalikan S. frugiferda.
\end{abstract}

Kata kunci: S. frugiperda, fenologi, jagung manis

\section{PENDAHULUAN}

Jagung manis (Zea mays L. Saccharata) merupakan komoditas yang cukup populer di Amerika, dan Asia salah satunya Indonesia (Riflianto dan Syukur, 2013). Di Indonesia, selain menjadi salah satu makanan pokok, jagung manis juga menjadi komoditas strategis dan bernilai ekonomis, serta memiliki peluang besar untuk dikembangkan (Rifkowaty, Irianto, dan Anto 2016; Sinaga, 2020). Cahya dan Herlina (2018) menjelaskan bahwa potensi produksi tanaman jagung manis pada dataran rendah mencapai 20,10 ton/ha untuk satu kali masa panen. Sementara itu, produktivitas jagung manis di Provinsi Jambi masih tergolong rendah karena hanya mencapai 6,094 ton/ha (BPS, 2018).

Rendahnya produktivitas jagung manis di Provinsi Jambi mengindikasikan bahwa terdapat kendala yang dihadapi petani dalam melakukan proses budidaya. Salah satu kendala yang seringkali dihadapi petani dalam membudidayakan tanaman jagung manis adalah adanya serangan organisme pengganggu tanaman (OPT). Keberadaan OPT yang menyerang tanaman menyebabkan pertumbuhan dan perkembangan tanaman menjadi tidak optimal, karena terganggunya beberapa fungsi organ tanaman (Nadrawati, Ginting dan Zarkani, 2019).

Salah satu hama penting tanaman jagung manis adalah fall armyworm (FAW) atau ulat grayak (Spodoptera frugiperda J.E. Smith). Larva S. frugiperda dapat merusak hampir pada semua bagian tanaman jagung. Hama ini bahkan dapat menyebabkan kegagalan pembentukan pucuk atau daun muda tanaman(Maharani, Dewi, Puspasari, Rizkie, Hidayat \& Dono.2019).Larva instar 1 awalnya memakan jaringan daun dan meninggalkan lapisan epidermis 
yang transparan. Larva instar 2 dan 3 membuat lubang gerekan pada daun dan memakan daun dari tepi hingga ke bagian dalam (Nonci, Kalqutny, Mirsam, Muis, Azrai dan Aqil. 2019).

S. frugiperda merupakan serangga asli daerah tropis dari Amerika Serikat hingga Argentina (Nonci, Kalqutny, Mirsam, Muis, Azrai dan Aqil. 2019). Hama ini pertama kali ditemukan di Indonesia pada awal tahun 2019 tepatnya di pertanaman jagung manis di daerah Sumatera (Kementan, 2019). Meskipun berstatus sebagai hama baru, serangan $S$. frugiperda sudah menyabar secara luas di Inonesia. Hal ini karena imago $S$. frugiperda memiliki kamampuan terbang yang kuat, sehingga dapat menyebar secara cepat dan sulit untuk dikendalikan.Selain itu, keberadaan $S$. frugiperda di pertanaman jagung juga sangat maerugikan bagi petani karena persentase serangannya dapat mencapai $100 \%$ (Bagariang, Tauruslina, Kulsum, Murniningtyas, Suyanto, Surono , Cahyana dan Mahmuda. 2020). Oleh karena itu, diperlukan pengetahuan yang baik agar tindakan pengendalian yang dilakukan berjalan secara efektif dan tidak menimbulkan permasalahan baru seperti resistensi, resurgensi, terbunuhnya musuh alami, dan keracunan pada ternak bahkan manusia akibat tindakan pengendalian yang tidak tepat.

Sehubungan dengan masih terbatasnya informasi rinci tentang hubungan fenologi tanamanjagung manis dengan perkembangan $S$. frugiperda, maka penelitian tentang perkembangan $S$. frugiperdapada tanaman jagung penting untuk dilakukan. Hal ini karena pemahaman mengenai perkembangan populasi hama serta kaitannya dengan fenologi tanaman merupakan pengetahuan dasar yang perlu dimiliki untuk menentukan tindakan pengendalian yang tepat (Gultom, Pangestiningsih dan Lubis. 2014).

\section{METODE PENELITIAN}

Penelitian dilaksanakan di Kebun Percobaan dan Laboratorium Hama Tanaman Fakultas Pertanian Universitas Jambi mulai bulan Desember 2020 hingga Februari 2021.

Penelitian dilakukan menggunakan metode ekplorasi pada pertanaman jagung seluas $500 \mathrm{~m}^{2}$. Eksplorasi dilakukan dengan cara mengamati perkembangan $S$. frugiperda pada beberapa fase pertumbuhan tanaman jagung. Secara umum, pertumbuhan tanaman jagung setelah perkecambahan terdiri dari beberapa fase, yaitu Fase V3-V5 (jumlah daun yang terbuka sempurna 3-5), Fase V6-V10 (jumlah daun terbuka sempurna 6-10), Fase V11- Vn (jumlah daun terbuka sempurna 11 sampai daun terakhir15-18), Fase Tasseling/VT (berbunga jantan), Fase R1 (silking), Fase R2 (blister), Fase R3 (masak susu), Fase R4 (dough), Fase R5 (pengerasan biji), dan Fase R6 (masak fisiologis) (Lee, 2007; Subekti, Syafruddin dan Sunarti. 2007).

Sebelum dilakuan eksplorasi, kegiatan pada penelitian ini diawali dengan proses budidaya tanaman jagung yang terdiri dari 4 tahap kegiatan, yaitu persiapan lahan, penanaman, pemeliharaan, dan pengamatan.

1. Persiapan lahan dilakukan dengan cara menggemburkan tanah sedalam $20-30 \mathrm{~cm}$ dan dibuat petakan setinggi $30 \mathrm{~cm}$ dengan luas $3 \times 2 \mathrm{~m}$. Lahan yang telah selesai dibuat kemudian diaplikasikan pupuk kandang dengan dosis $9 \mathrm{~kg} /$ petakan (Hutosoit, Chozin dan Setyowati2020).

2. Benih jagung manis ditanam dengan jarak $100 \times 30 \mathrm{~cm}$ antar tanaman dalam baris. Lubang tanam dibuat dengan cara ditugal dengan kedalaman $3 \mathrm{~cm}$. Total lubang tanam dalam satu petak lahan adalah 18 lubang dan pada setiap lubang tanam ditanam 1 benih jangung.

3. Pemeliharaan tanaman terdiri dari penyiraman, penyulaman, pemupukan dan penyiangan gulma. Penyiraman tanaman dilakukan 2 kali sehari yaitu pagi dan sore, tetapi jika kondisi tanah masih lembab dan terjadi hujan maka tidak dilakukan penyiraman. Penyulaman dilakukan terhadap tanaman yang mati atau tidak tumbuh dengan baik dan dilakukan sampai tanaman berumur 6 hari setelah tanam (hst). Pemupukan dilakukan dengan menggunakan pupuk anorganik sintetik yaitu Urea, TSP, dan KCL yang diaplikasikan 12 hst, dengan dosis Urea 150 gr/petakan, TSP 105 gr/petakan dan KCL 90 gr/petakan (Alatas, Sirajuddin, Irfan, dan Annisava. 2019). Setelah tanaman berumur 3 hingga 4 minggu maka dilakukan penyiangan terhadap gulma atau tanaman pengganggu lainnya. Penyiangan berikutnya dilakukan dengan melihat frekuensi gulma yang ada.

4. Tanaman sampel terdiri dari 4 petakan, yang ditentukan secara sistematik berpola $\mathrm{S}$ dari 28 petak tanaman. Dari satu petakan tanaman sampel ke petakan tanaman sampel lainnya berjarak 7 petakan tanaman. Pada setiap petak sampel, semua tanaman (18 tanaman) dijadikan sebagai tanaman sampel untuk menghitung persentase tanaman terserang.

Pengamatan perkembangan $S$. frugiperda dilakukan pada setiap fase pertumbuhan tanaman jagung mulai dari fase V3-V5 sampai pada fase R6. Variabel yang diamati pada penelitian ini adalah populasi $S$. frugiperda dan persentase tanaman terserang $S$. frugiperda.

\section{a. Populasi S. frugiperda}

Pengamatan populasi $S$. frugiperda dilakukan secara langsung, yaitu dengan memeriksa keberadaan larva $S$. frugiperda pada daun, bunga, dan buah (tongkol). Jika ditemukan bekas gerekan S. frugiperda pada pucuk dan tongkol, maka bagian tanaman tersebut dibuka untuk mengetahui jumlah larva $S$. frugiperda yang ada di dalamnya. 
Setiap larva yang ditemukan dicatat sesuai dengan waktu pengamatan, petak sampel, dan nomor tanaman sampel. S. frugiperdaakan dibawa ke laboratorium dalam botol koleksi yang berisi alkohol $70 \%$ untuk diidentifikasi lebih lanjut.

\section{b. Persentase tanaman terserang $S$. frugiperda}

Pengamatan persentase tanaman terserang dilakukan dengan cara menghitung semua tanaman yang terserang S. frugiperda. Persentase tanaman terserang dihitung menggunakan rumus Wiryadiputra (2012), yaitu:

$P=\frac{H}{T} \times 100 \%$

Keterangan:

$\mathrm{P} \quad$ : Persentase serangan

$\mathrm{H} \quad$ : Jumlah tanaman terserang

T : Jumlah tanaman total

Data hasil pengamatan ditabulasi dan disusun dalam bentuk tabel dan gambar. Data tersebut kemudian dijelaskan secara deskriptif dengan menghubungkan fenologi tanaman dan perkembagan S. frugiperda.

\section{HASIL DAN PEMBAHASAN}

\section{Populasi S. frugiperda Pada Beberapa Fase Pertumbuhan Tanaman Jagung Manis}

Hasil pengamatan menunjukkan bahwa larva $S$. frugiperda pertama kali ditemukan pada fase V6-V10, yaitu sebanyak 3 ekor. Berikutnya pada fase V11-Vn dan VT-R1 larva S. frugiperdayang ditemukan meningkat menjadi 4 ekor dan 6 ekor. Populasi Spodoptera frugiperda bahkan mengalami peningkatan yang cukup signifikan, yaitu 10 ekor per 12 tanaman pada fase R2-R5, dan 21 ekor per 12 tanaman pada fase R6 atau pada fase masak fisiologis (Tabel 1).

Tabel 1. Fenologi tanaman jagung manis, populasi dan gejala serangan S. frugiperda

\begin{tabular}{cccl}
\hline No & $\begin{array}{c}\text { Fase pertumbuhan } \\
\text { tanaman }\end{array}$ & $\begin{array}{c}\text { Populasi } \\
\text { S. frugiperdaper 12 tanaman }\end{array}$ & \multicolumn{1}{c}{ Gejala serangan } \\
\hline 1 & V3-V5 & 0 & $\begin{array}{l}\text { Pada setiap tanaman sampel masih dalam kondisi sehat, } \\
\text { belum nampak gejala serangan } \\
\text { Terlihat gejala serangan pada daun tanaman sampel } \\
\text { seperti lapisan epidermis yang trasnparan, bekas gerekan } \\
\text { dan adanya feses larva pada daun muda. }\end{array}$ \\
2 & V6-V10 & 3 & $\begin{array}{l}\text { Terdapat bekas gerekan dan feses pada daun } \\
\text { Terdapat bekas gerekan dan feses pada daun } \\
\text { Adanya lobang gerekan dan feses pada tongkol } \\
\text { Terlihat tongkol yang diserang S. frugiperda terdapat } \\
\text { banyak feses, dan ujung tongkolnya rusak }\end{array}$ \\
\hline
\end{tabular}

Secara umum, populasi $S$. frugiperda yang ditemukan pada tanaman sampel terus mengalami peningkatan seiring dengan perubahan fase pertumbuhan tanaman (Tabel 1).Hal ini karena S. frugiperda dapat menyerang pada semua fase pertumbuhan tanaman jagung, baik fase vegetatif maupun fase generatif (Pebrianti dan Siregar,2021). Kerusakan pada tanaman biasanya ditandai dengan bekas gerekan larva, yaitu terdapat serbuk kasar menyerupai serbuk gergaji pada permukaan atas daun, atau disekitar pucuk tanaman jagung (Megasari, 2021). Pucuk tanaman yang terserang $S$. frugiperda ketika daun belum membuka penuh (kuncup) tampak berlubang dan terdapat banyak kotoran fases larva. Jika daun sudah terbuka maka akan terlihat banyak bagian daun yang rusak, berlubang bekas gerekan larva (Maharani, Dewi, Puspasari, Rizkie, Hidayat \& Dono. 2019).

Tingginya populasi $S$. frugiperda yang ditemupakan pada fase fase R2-R5 dan pada fase R6 karena ketersediaan tongkol jagung yang menjadi makanan bagi S. frugiperda. Rondo, Sudarma danWijana(2016) menjelaskan bahwa tingginya populasi ulat tongkol dipengaruhi oleh ketersediaan buah jagung yang menjadi pakan utama untuk mendukung perkembangannya. Pakan merupakan salah satu faktor penting yang dibutuhkan serangga sebagai sumber gizi untuk hidup dan berkembang (Jumar, 2000). Jika pakan tersedia dengan kualitas dan kuantitas yang cukup, maka populasi serangga akan naik dengan cepat. Sebaliknya, jika ketersedian pakan kurang maka populasi serangga juga akan menurun. 


\section{Persentase Tanaman Terserang $S$. frugiperda}

Sebagaimana hasil pengamatan terhadap populasi $S$. frugiperda, persentase tanaman jagung yang terserang juga baru ditemukan pada fase V6 atau ketika tanaman berumur 14 hst. Persentase tanaman terserang terus meningkat hingga fase R6 (Tabel 2).

Tabel 2. Persentase tanaman terserang $S$. Frugiperda pada daun

\begin{tabular}{ccc}
\hline No. & Fase tanaman & Serangan $(\%)$ \\
\hline 1. & V3-V5 & 0 \\
2. & V6-V10 & 50 \\
3. & V11-Vn & 51,41 \\
4. & VT-R1 & 54,61 \\
5. & R2-R5 & 63,38 \\
6. & R6 & 78,72 \\
\hline
\end{tabular}

Persentase tanaman terserang S. Frugiperdapaling tinggi terjadi pada saat tanaman memasuki fase R6, yaitu mencapai $78,72 \%$. Hal ini berarti bahwa serangan S. frugiperdasudah tersebar hampir di seluruh tanaman. Tingginya pesentase tanaman terserang pada fase R6 berkaitan dengan tingkat populasi hama yang juga tinggi pada saat tanaman memasuki fase R6.Headly (1982) menyatakan bahwa semakin tinggi populasi hama pada stadia aktif akan menyebabkan kerusakan tanaman yang semakin tinggi pula.

Serangan $S$. frugiperda diawali dengan adanya aktivitas memakan jaringan permukaan daun, sehingga daun tampak transparan seperti jendela yang berukuran diameter kurang dari $5 \mathrm{~mm}$. Serangan lanjut ditandai semakin besarnya lubang bekas gigitan dengan bentuk yang tidak beraturan dan adanya kotoran seperti serbuk segar. Serbuk atau frass segar ditemukan di sekitar tempat makan (feeding area) dan di atas permukaan daun. Sementara itu, gejala kerusakan yang lebih parah terjadi ketika larva menggerek sampai bagian pucuk tanaman dan memakan dari bagian dalam, sehingga jika pucuknya terbuka daun pucuk tersebut telah rusak dan banyak ditemukan frass segar seperti serbuk gergaji (Gambar 1).
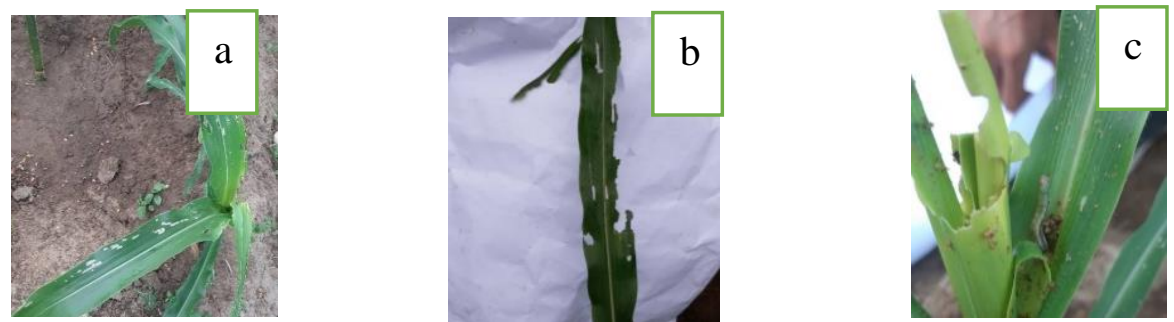

Gambar 1. (a) Serangan awal pada daun, (b) Serangan lanjutan pada daun, (c) S. frugiperda yang menyerang daun

Dari penjelasan diatas, dapat disimpulkan bahwa:

\section{KESIMPULAN}

1. Populasi $S$. frugiperda pada setiap fase pertumbuhan terus naik, populasi tertinggi $S$. frugiperda ditemukan pada fase R6 atau pada fase masak fisiologis yaitu sebanyak 21 ekor per 12 tanaman jagung.

2. Persentase serangan $S$. frugiperda setiap fasenya terus mengalami peningkatan, persentase serangan tertinggi terdapat pada fase R6, yaitu 78,72\%. Tingginya pesentase tanaman terserang berkaitan dengan tingkat populasi hama yang juga paling tinggi pada fase tersebut.

3. Serangan $S$. frugiperda mulai terlihat pada fase R2-R5 yaitu 10\%. dan meningkat secara signifikan pada fase R6 menjadi $68,57 \%$. Hal ini karena pada fase kemunculan tongkol, pakan larva akan beralih dari daun ke tongkol.

\section{DAFTAR PUSTAKA}

Alatas, S., I. Sirajuddin, M.Irfan, dan A.R. Annisava. 2019. Pertumbuhan Dan Hasil Jagung Manis (Zea mays Saccharatasturt.) yang ditanam dengan Tanaman Sela Pegagan (Centella msiatica (L.) Urban) pada Beberapa Taraf Dosis Pupuk Anorganik. Jurnal Agroteknologi. Vol. 10 (1) : 23-32.

Badan Pusat Statistik. 2018. Tanaman Pangan. www.BPS.go. id. Diakses tanggal 1 Agustus 2021.

Bagariang, W., E. Tauruslina, U. Kulsum, T. Murniningtyas, H. Suyanto, Surono , N. A . Cahyana dan D. Mahmuda. 2020. Efektifitas Insektisida Berbahan Aktif Klorantraniliprol terhadap Larva Spodoptera frugiperda. Jurnal Proteksi Tanaman (Journal of Plant Protection) ISSN : 2580-0604 Online ISSN: 26213141, 4(1): 29-37.

Cahya, J. E dan N. Herlina. 2018. Uji Potensi 6 Varietas Jagung Manis (Zea mays saccharata Sturt) di Dataran Rendah Kanupaten Pemakasan. Jurnal Produksi Tanaman. Vol. 6 (1) : 92-100. 
Gultom RM, Y Pangestiningsih, dan L Lubis. 2014. Pengaruh beberapa insektisida terhadap hamaLamprosema indicata F. dan Spodoptera litura F. pada tanaman kedelai (Glycine max (L) MERRIL.). Jurnal Agroekoteknologi. Vol. 2 (3) : 1159-1164.

Headley, J.C., 1982. Defining the economic threshold. Dalam Pest Control Strategies for the future. Nat. Acad. Of Science. Washington D.C. p 100-108.

Hutosoit, R.I., M. Chozin dan N. Setyowati. 2020. Pertumbuhan dan Hasil Delapan Genotipe Jagung Manis yang dibudidayakan secara Organik di Lahan Rawa Lebak. Jurnal Ilmu-ilmu Pertanian Indonesia. Vol. 22 (1) : 45-51.

Jumar, 2000. Entomologi Pertanian. PT Rineka Cipta. Jakarta.

Kementerian Pertanian. 2019. Pengenalan Fall Armyworm (Spodoptera frugiperda J. E. Smith) Hama Baru pada Tanaman Jagung di Indonesia. Jakarta (ID): Balai Penelitian Tanaman Serealia. 64 p.

Lee, C. 2007. Corn growth and development. www.uky.edu/ag/grain crops diakses pada 22 Mei 2020.

Maharani, Y., V.K. Dewi,L.T. Puspasari, L. Rizkie, Hidayat, Y. Bidayat\&D. Dono. 2019. Cases of Fall Army Worm Spodoptera frugiperda JE Smith (Lepidoptera: Noctuidae) Attack on Maize in Bandung, Garut and Sumedang District, West Java. CROPSAVER-Journal of Plant Protection, 2(1), 38-46.

Megasari, D., \& Khoiri, S. 2021. Tingkat serangan ulat grayak tentara Spodoptera frugiperda JE Smith (Lepidoptera: Noctuidae) pada pertanaman jagung di Kabupaten Tuban, Jawa Timur, Indonesia. Agrovigor: Jurnal Agroekoteknologi, 14(1), 1-5.

Nadrawati, S. Ginting, \& A. Zarkani. 2019. Identifikasi Hama Baru Dan Musuh Alaminya Pada Tanaman Jagung, Di Kelurahan Sidomulyo, Kecamatan Seluma, Bengkulu.

Nonci N, SH Kalqutny, H Mirsam, A Muis, M Azrai dan M Aqil. 2019. Pengenalan Fall Armyworm (Spodoptera frugiperda J.E. Smith) Hama Baru Pada Tanaman Jagung di Indonesia. Balai Penelitian Tanaman Serealia. Maros.

Pebrianti, H.P \& Siregar, H.M. 2021. Serangan Ulat Grayak Jagung Spodoptera frugiperda (Lepidoptera: Noctuidae) pada Tanaman Jagung di Kabupaten Muaro Jambi, Jambi. Jurnal Agrohita, 6(1), 31-35.

Rifianto A dan M. Syukur. 2013. Jagung Manis. ISBN: 9789790025912. Penebar Swadaya Jakarta.

Rifkowaty, E.E., Prawiro, I.S., Susanto, A. 2016. Ipteks Bagi Masyarakat (Ibm) Pengembangan Agroindustri Jagung Manis di Desa Kalinilam Kecamatan Deltapawan Kabupaten Ketapang. Jurnal Agromix. Vol 7 (2) : 65-76.

Rondo S.F., I.M. Sudarma, G. Wijana. 2016. Dinamika Populasi Hama dan Penyakit Utama Tanaman Jagung Manis (Zea mays saccharata Sturt) pada Lahan Basah dengan Sistem Budidaya Konvensional serta Pengaruhnya terhadap Hasil di Denpasar-Bali. Jurnal Agrotop, 6 (2): 128-136.

Sinaga, O.S. 2020. Penyusunan Fungsi Produksi Polinomial pada Produksi Jagung Manis di Desa Manunggal Jaya, Tenggarong Seberang. Jurnal Magrobisnis. Vol 20 (1) : Hal 147-155.

Subekti N.A, R.E Syafruddin, S. Sunarti. 2007. Morfologi Tanaman dan Fase Pertumbuhan Jagung. Balai Penelitian Tanaman Serealia, Maros.

Wiryadiputra S. 2012. Keefektifan insektisida cyantraniliprole terhadap hama penggerek buah kopi (Hypothenemus hampei) pada kopi arabika. Jurnal Pelita Perkebunan 28(2): 100-110. 